\title{
Penerapan Text Mining untuk Melakukan Clustering Data Tweet Shopee Indonesia
}

\author{
Dwi Smaradahana Indraloka, dan Budi Santosa \\ Departemen Matematika, Fakultas Matematka dan Ilmu Pengetahuan Alam, Institut Teknologi Sepuluh Nopember \\ (ITS) \\ e-mail:budi_s@ie.its.ac.id
}

\begin{abstract}
Abstrak-Pelaku bisnis dapat memanfaatkan followers akun Twitter mereka sebagai sarana untuk melakukan advertising. Sebanyak 37,5\% pengguna Twitter, menemukan pelaku bisnis baru dikarenakan membaca retweet dari tweet yang dibuat oleh pelaku bisnis tersebut. Dengan mengetahui jenis konten tweet yang banyak dilakukan retweet oleh followers-nya, pelaku bisnis dapat menggunakan jenis konten tweet tersebut sebagai sarana untuk melakukan advertising kepada pengguna Twitter. Dalam penelitian ini, dilakukan penerapan Text Mining untuk melakukan clustering dengan metode $K$-means pada data tweet Shopee Indonesia untuk mengetahui jenis konten tweet yang banyak dilakukan retweet oleh followers Shopee Indonesia. Hasil yang didapat adalah jenis konten pada klaster yang memiliki jumlah retweet yang tinggi diantaranya tentang kuis berhadiah (klaster 4, klaster 20, dan klaster 28), ulang tahun Shopee Indonesia (klaster 11), dan hobi, kuis, dan lifestyle (klaster 7), sehingga Shopee Indonesia dapat menggunakan jenis konten tweet tersebut sebagai sarana untuk melakukan advertising kepada pengguna Twitter.
\end{abstract}

Kata Kunci-Advertising, Clustering, K-means, Text Mining, Twitter.

\section{PENDAHULUAN}

A DVERTISING telah berkembang menjadi sistem komunikasi yang sangat penting antara pelaku bisnis dan konsumen. Pelaku bisnis sangat mengandalkan advertising untuk membantu memasarkan produk atau layanan yang mereka miliki agar dapat dikenal oleh konsumen. Kelebihan tersebut menjadikan advertising memiliki peranan utama dalam program pemasaran [1]. Sebagian besar pelaku bisnis saat ini, menggunakan media sosial sebagai sarana untuk melakukan advertising [2].

Twitter merupakan salah satu media sosial paling populer di Indonesia [3]. Berdasarkan data statistik dari Statista Inc., jumlah pengguna aktif Twitter di Indonesia pada tahun 2016 sebanyak 24,34 juta orang. Pengguna Twitter dapat membuat sebuah pesan pendek yang disebut dengan tweet, dimana melalui tweet tersebut, pengguna Twitter dapat saling berhubungan, berbagi pendapat, dan menemukan kabar dari berbagai penjuru dunia. Sebagian besar pengguna Twitter juga memanfaatkan media sosial ini untuk menemukan pelaku bisnis, dimana mereka akan menjadi pengikut (followers) dan berinteraksi dengan pelaku bisnis tersebut [4].

Pelaku bisnis dapat memanfaatkan followers akun Twitter mereka sebagai sarana untuk melakukan advertising. Dengan menggunakan perintah retweet pada Twitter, followers dapat menyebarkan tweet yang dibuat oleh pelaku bisnis. Sebanyak $37,5 \%$ pengguna Twitter, menemukan pelaku bisnis baru dikarenakan membaca retweet dari tweet yang dibuat oleh pelaku bisnis tersebut. Pelaku bisnis tentunya dituntut untuk mampu memahami jenis konten dalam sebuah tweet yang mendapatkan respon positif dari followers, karena setiap kata, foto, dan video yang dicantumkan didalam sebuah tweet akan memberikan dampak kepada followers [5],[6], dan [7].

Pengumpulan data tweet dari Twitter dapat dilakukan dengan mengintegrasikan Twitter API dan R Studio. Untuk mempermudah mengetahui jenis konten dari sejumlah data tweet, maka perlu dilakukan proses Text Mining terhadap data tweet tersebut dengan menerapkan teknik clustering [8]. Pada Text Mining, teknik clustering digunakan untuk mengelompokkan data tekstual berdasarkan kesamaan konten yang dimiliki ke dalam beberapa klaster, sehingga didalam setiap klaster akan berisi data tekstual dengan konten semirip mungkin [9].

Salah satu metode yang digunakan untuk melakukan clustering adalah metode K-means. Keuntungan dari menggunakan metode $K$-means untuk melakukan clustering adalah tidak memerlukan jumlah iterasi yang banyak untuk mendapatkan hasil clustering yang baik, dimana hal ini sangat tepat untuk diterapkan dalam melakukan clustering dengan jumlah data yang besar [10]. Penentuan jumlah klaster terbaik dilakukan dengan menggunakan metode Silhouette coefficient. Shopee Indonesia merupakan salah satu pelaku bisnis di Indonesia yang bergerak di bidang e-commerce dan menggunakan media sosial Twitter sebagai sarana untuk melakukan advertising. Terhitung pada tanggal 1 April 2017, Shopee Indonesia memiliki jumlah followers Twitter sebanyak 17,5 ribu dan jumlah tweet sebanyak 13,2 ribu. Jumlah tersebut masih sedikit apabila dibandingkan dengan pelaku bisnis pesaing dari Shopee Indonesia, diantaranya OLX Indonesia yang memiliki jumlah followers Twitter sebanyak 202 ribu dan jumlah tweet sebanyak 20,7 ribu, Tokopedia yang memiliki jumlah followers Twitter sebanyak 121 ribu dan jumlah tweet sebanyak 26,2 ribu, dan Bukalapak yang memiliki jumlah followers Twitter sebanyak 113 ribu dan jumlah tweet sebanyak 47,4 ribu. Dengan menemukan jenis konten tweet yang banyak dilakukan retweet oleh followers dari Shopee Indonesia, diharapkan semakin banyak pengguna Twitter yang menjadi konsumen dari Shopee Indonesia.

\section{DESKRIPSI PERMASALAHAN}

Pengolahan dan pengambilan informasi dari sebuah data tekstual merupakan permasalahan yang tidak dapat diselesaikan dengan menggunakan teknik Data Mining. 
Diperlukan beberapa tahapan proses tambahan agar data tekstual yang memiliki format tidak teratur dapat dilakukan pengolahan dan pengambilan informasi, tahapan proses tersebut dikenal dengan istilah Text Mining. Penjelasan tahapan proses Text Mining menurut Feldman dan Sanger (2007) adalah sebagai berikut:

\section{A. Text preprocessing}

Merupakan tahapan awal dari Text Mining, tahap ini meliputi proses untuk mempersiapkan data tekstual yang akan digunakan agar dapat diproses pada tahapan berikutnya. Proses yang dilakukan pada tahapan ini antara lain:

1. Case folding yaitu merubah semua karakter huruf pada sebuah kalimat menjadi huruf kecil dan menghilangkan karakter yang dianggap tidak valid seperti angka, tanda baca, dan Uniform Resources Locator (URL).

2. Tokenizing yaitu memotong sebuah kalimat berdasarkan tiap kata yang menyusunnya.

3. Stemming yaitu merubah berbagai kata berimbuhan menjadi kata dasarnya, tahap ini pada umumnya dilakukan untuk teks dengan bahasa Inggris, karena teks dengan bahasa Inggris memiliki struktur imbuhan yang tetap.

4. Tagging yaitu merubah berbagai kata dalam bentuk lampau menjadi kata awalnya, tahap ini pada umumnya dilakukan untuk teks dengan bahasa Inggris atau bahasa lainnya yang memiliki bentuk lampau.

\section{B. Feature selection}

Merupakan tahapan untuk mengurangi dimensi dari sebuah data tekstual sehingga hasil dari proses Text Mining memiliki kualitas yang lebih baik. Proses yang dilakukan pada tahapan ini adalah stopword removal yaitu menghilangkan kata-kata yang dianggap tidak penting atau tidak menggambarkan isi dari sebuah kalimat.

\section{Text Representation}

Merupakan tahapan merubah data tekstual menjadi representasi yang lebih mudah untuk diproses. Pada tahapan ini, sebuah kalimat direpresentasikan sebagai objek dan katakata yang menyusunnya direpresentasikan sebagai fitur. Data tekstual akan membentuk sebuah ruang dengan jumlah objek sebanyak jumlah kalimat yang ada dan jumlah fitur sebanyak jumlah kata yang berbeda.

\section{Application of Text Mining Techniques}

Merupakan tahapan utama pada proses Text Mining. Pada tahapan ini dilakukan penerapan teknik yang digunakan untuk pengambilan informasi dari data tekstual yang telah diproses sebelumnya. Terdapat beberapa teknik yang dapat digunakan diantaranya classification, clustering, information extraction, trend analysis, distribution analysis, dan association rules. Pemilihan teknik yang digunakan disesuaikan dengan jenis informasi yang ingin diambil dari data tekstual yang tersedia.

\section{METODE PENYELESAIAN}

Algoritma proses Text Mining dirancang untuk melakukan clustering data tweet Shopee Inddonesia. Berikut adalah tahapan proses Text Mining yang telah dirancang:

\section{A. Authentication}

Pada saat bergabung dengan Twitter API, didapatkan beberapa kode berupa consumer key, consumer secret, access token, dan access key.

Tabel 1.

Kode yang didapat pada saat bergabung dengan Twitter API

\begin{tabular}{ll}
\hline $\begin{array}{l}\text { Consumer } \\
\text { key }\end{array}$ & eqInJRxlWmUCcHFBxWGLT5JUS \\
$\begin{array}{l}\text { Consumer } \\
\text { secret }\end{array}$ & PVIJTrxuIxjAAXIIXYkiEies2vucy1NuUuRnArIDW6c \\
Access & o vb0rYe \\
token & 828496585558351872- \\
Access key & FPUfdSsBB8dSHLiYoSZqtZXK60v1Q82 \\
& ij6C8mYemRtCUsb6boUBViFBkPFvW0FJtv7q0n9Y \\
\hline
\end{tabular}

Kode di atas digunakan untuk proses integrasi antara Twitter API dengan software $\mathrm{R}$ Studio, dimana proses integrasi dilakukan dengan menggunakan fungsi 'setup_twitter_oauth (consumer_key, consumer_secret, access_token, access_key)'.

\section{B. Pengambilan Data dari Twitter}

Pegambilan data dilakukan secara real time dari Twitter dengan menggunakan fungsi 'tweets $=$ userTimeline ("ShopeeID", $\mathrm{n}=$ 2000, excludeReplies = TRUE)'.

Tabel 2.

Contoh data tweet yang didapatkan dari timeline Twitter Shopee Indonesia

\begin{tabular}{clcc}
\hline \hline $\begin{array}{c}\text { Nomer } \\
\text { Tweet }\end{array}$ & \multicolumn{1}{c}{ Teks Tweet } & $\begin{array}{c}\text { Tanggal } \\
\text { Tweet }\end{array}$ & $\begin{array}{c}\text { Jumlah } \\
\text { Retweet }\end{array}$ \\
\hline \multirow{5}{*}{1} & $\begin{array}{l}\text { Hey Shopeeholics! Mau tahu } \\
\text { siapa saja 3 besar jawara video } \\
\text { \#ParodiIklanShopee? Cek di IG } \\
\text { kami >> }\end{array}$ & $\begin{array}{c}01 / 04 / 20 \\
\text { instagram.com/shopee_id }\end{array}$ & 0 \\
& $\begin{array}{l}\text { Ayo ikutan Kuis kali ini di IG/FB } \\
\text { Shopee ya. 2 Orang yg beruntung } \\
\text { akan mendapatkan Brush Set dari } \\
\text { Shopee loh! }\end{array}$ & $31 / 03 / 20$ & \\
& $177: 37$ & 3 \\
\hline \hline
\end{tabular}

\section{Case Folding}

Pada proses case folding, semua huruf pada tiap tweet dirubah menjadi huruf kecil dengan menggunakan fungsi 'myCorpus = tm_map (myCorpus, tolower)', karakter yang dianggap tidak valid seperti angka dan tanda baca dihilangkan dengan menggunakan fungsi 'myCorpus = tm_map (myCorpus, content_transformer(removeNumPunct))', dan Uniform Resources Locator (URL) dihilangkan dengan menggunakan fungsi 'myCorpus = tm_map (myCorpus, content_transformer(removeURL))'.

Tabel 3.

Contoh hasil proses case folding

\begin{tabular}{cl}
\hline \hline $\begin{array}{c}\text { Nomer } \\
\text { Tweet }\end{array}$ & \multicolumn{1}{c}{ Teks Tweet Hasil Case Folding } \\
\hline 1 & $\begin{array}{l}\text { hey shopeeholics mau tahu siapa saja besar jawara video } \\
\text { parodiiklanshopee cek di ig kami } \\
\text { ayo ikutan kuis kali ini di igfb shopee ya orang yg } \\
\text { beruntung akan mendapatkan brush set dari shopee loh }\end{array}$ \\
\hline \hline
\end{tabular}




\section{Tokenizing}

Pada proses tokenizing, pemotongan kalimat pada tweet berdasarkan tiap kata yang menyusunnya dilakukan dengan menggunakan fungsi ' $\mathrm{tdm}=$ DocumentTermMatrix (myCorpus)'.

Tabel 4.

Contoh hasil proses tokezining

\begin{tabular}{clll}
\hline \hline Nomer & \multicolumn{1}{c}{ Hasil Tokenizing } & $\begin{array}{c}\text { Nomer } \\
\text { Tweet }\end{array}$ & \multicolumn{1}{c}{ Hasil Tokenizing } \\
\hline Tweet & hey & ayo \\
& shopeeholics & ikutan \\
& mau & kuis \\
& tahu & kali \\
& siapa & ini \\
& saja & di \\
& besar & igfb \\
& jawara & shopee \\
& video & ya \\
& parodiiklanshopee & & orang \\
& cek & yg \\
& di & beruntung \\
& ig & akan \\
& kami & mendapatkan \\
& & brush \\
& & set \\
& & dari \\
& & shopee \\
\hline \hline
\end{tabular}

\section{E. Stopword Removal}

Pada proses stopword removal, penghilangan kata-kata yang dianggap tidak penting atau tidak menggambarkan isi dari sebuah tweet dilakukan dengan menggunakan fungsi 'myCorpus = tm_map (myCorpus, removeWords, custom_stopwords)'.

Tabel 5.

Contoh hasil proses stopword removal

\begin{tabular}{clll}
\hline \hline $\begin{array}{c}\text { Nomer } \\
\text { Tweet }\end{array}$ & \multicolumn{1}{c}{$\begin{array}{c}\text { Hasil Stopword } \\
\text { Removal }\end{array}$} & $\begin{array}{c}\text { Nomer } \\
\text { Tweet }\end{array}$ & \multicolumn{1}{c}{$\begin{array}{c}\text { Hasil Stopword } \\
\text { Removal }\end{array}$} \\
\hline \multirow{4}{*}{ hey } & & ayo \\
& shopeeholics & & ikutan \\
& tahu & kuis \\
& besar & kali \\
& jawara & igfb \\
& video & & shopee \\
1 & parodiiklanshopee & & ya \\
& cek & orang \\
& ig & 2 & yg \\
& & & beruntung \\
& & & mendapatkan \\
& & brush \\
& & set \\
& & shopee \\
\hline \hline
\end{tabular}

\section{F. Text Representation}

Pada proses text representation, perubahan data tweet menjadi sebuah matriks dengan baris berupa nomor dari tweet dan kolom berupa seluruh kata penyusun data tweet dilakukan dengan menggunakan fungsi 'matriks_kata = as.matrix $(\mathrm{tdm})$ '.

Berdasarkan hasil text representation, banyaknya seluruh kata yang menyusun 498 tweet dari Shopee Indonesia adalah sebanyak 1335 kata. Seluruh kata tersebut menjadi variabel dari tiap tweet, dengan komponen dari matriks berupa jumlah dari suatu kata yang ada pada tiap tweet.

\begin{tabular}{rrrrrrrr}
\multicolumn{7}{c}{ Contoh hasil proses text representation } \\
\hline \hline $\begin{array}{l}\text { Nomer } \\
\text { Tweet }\end{array}$ & ayo & besar & beruntung & $\ldots$ & video & ya & yg \\
\hline 1 & 0 & 1 & 0 & $\ldots$ & 1 & 0 & 0 \\
2 & 1 & 0 & 1 & $\ldots$ & 0 & 1 & 1 \\
\hline \hline
\end{tabular}

\section{G. Penentuan Jumah Klaster Terbaik}

Penentuan jumlah klaster terbaik dilakukan berdasarkan hasil perhitungan nilai Silhouette Coefficient dengan menggunakan fungsi 'fviz_nbclust (matriks_kata, kmeans, method = "silhouette", $\mathrm{k} \cdot \mathrm{max}=50)$ '. Perhitungan nilai Silhouette Coefficient dilakukan untuk k $=1$ sampai $\mathrm{k}=50$ dan didapat $\mathrm{k}$ terbaik adalah $\mathrm{k}=28$. Hasil perhitungan $\mathrm{k}$ terbaik digunakan untuk proses clustering dengan $K$-means.

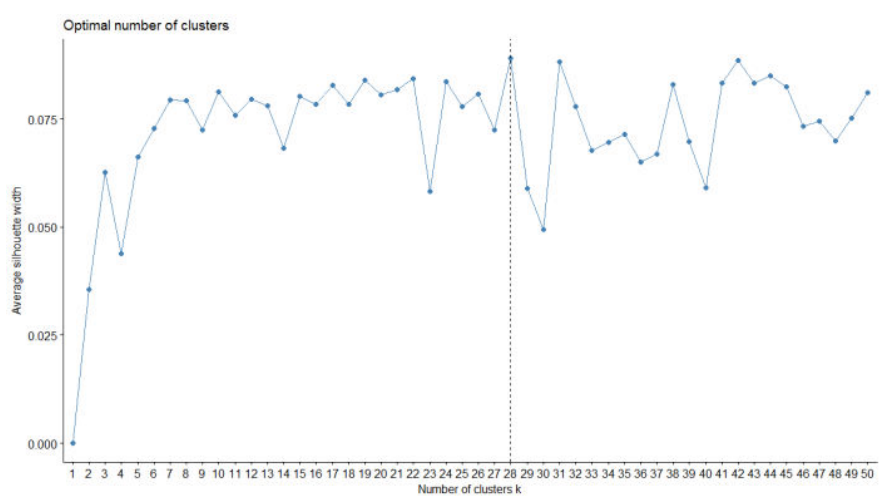

Gambar 1. Nilai Silhouette Coefficient pada Jumlah Klaster Sebanyak 1 sampai 50.

\section{H. Clustering dengan K-means}

Proses clustering dengan K-means dilakukan dengan menggunakan fungsi ' $k$ means_i $=$ kmeans (matriks_kata, 28, 100)' dengan jumlah klaster sebanyak 28 klaster dan jumlah iterasi sebanyak 100 iterasi.

Tabel 7.

Hasil clustering dengan $k$-means

\begin{tabular}{|c|c|c|}
\hline $\begin{array}{l}\text { Nomor } \\
\text { Klaster }\end{array}$ & Nomor Tweet & $\begin{array}{r}\text { Jumlah } \\
\text { Tweet }\end{array}$ \\
\hline 1 & $\begin{array}{l}56,67,68,69,74,80,82,84,86,89,90,93,98, \\
103,106\end{array}$ & 15 \\
\hline 2 & $2,9,34,39,43,46,52$ & 7 \\
\hline 3 & $331,392,396,403,405,407,412,413$ & 8 \\
\hline$:$ & $\vdots$ & : \\
\hline 26 & $11,61,232,279,322,365,375,385,453$ & 9 \\
\hline 27 & $\begin{array}{l}127,206,218,251,288,293,309,310,323,357, \\
359,366,388,442,474,476,484,489\end{array}$ & 18 \\
\hline 28 & $32,197,431,444,454,463,471,481,493$ & 9 \\
\hline
\end{tabular}

\section{Penentuan Jenis Konten Tweet tiap Klaster}

Proses pencarian kata yang paling sering muncul pada masing-masing klaster dilakukan dengan menggunakan fungsi 'cat(names(sort_kata)[1:10]', dimana diambil sebanyak sepuluh kata yang paling sering muncul.

Tabel 8.

Kata paling sering muncul dan jenis konten tweet pada tiap klaster

\begin{tabular}{lll}
\hline \hline Nomor & Kata Paling Sering Muncul & Jenis Konten Tweet \\
\hline
\end{tabular}




\begin{tabular}{|c|c|c|}
\hline 1 & $\begin{array}{l}\text { gunakan, kode, voucher, } \\
\text { dapatkan, potongan, untuk, } \\
\text { kategori, berlaku, hari, ini }\end{array}$ & $\begin{array}{l}\text { Kode voucher untuk } \\
\text { potongan harga }\end{array}$ \\
\hline 2 & $\begin{array}{l}\text { ayo, ikutan, kuis, di, fbig, } \\
\text { shopee, ya, orang, yang, } \\
\text { beruntung }\end{array}$ & Kuis berhadiah \\
\hline 3 & $\begin{array}{l}\text { tunjukin, foto, kamu, gaya, } \\
\text { belanja, terbaik, hari, ini, } \\
\text { dapatkan, iphone }\end{array}$ & $\begin{array}{l}\text { Kontes foto saat } \\
\text { berbelanja }\end{array}$ \\
\hline : & & : \\
\hline 26 & $\begin{array}{l}\text { ini, dia, pemenang, seller, of, } \\
\text { the, month, bulan, vote, } \\
\text { terbanyak }\end{array}$ & $\begin{array}{l}\text { Pengumuman pemenang } \\
\text { Seller of The Month }\end{array}$ \\
\hline 27 & $\begin{array}{l}\text { selamat, untuk, para, } \\
\text { pemenang, cepat, kirimkan, } \\
\text { data, kamu, kami, tunggu }\end{array}$ & $\begin{array}{l}\text { Pengumuman pemenang } \\
\text { kuis }\end{array}$ \\
\hline 28 & $\begin{array}{l}\text { di, fbig, shopee, dapatkan, } \\
\text { paket }\end{array}$ & Kuis berhadiah \\
\hline
\end{tabular}

\section{J. Perhitungan Rata-Rata Jumlah Retweet tiap Klaster}

Proses perhitungan rata-rata jumlah retweet tiap klaster dilakukan terhadap hasil dari clustering dengan $K$-means.

Tabel 9.

Perhitungan rata-rata jumlah retweet tiap klaster

\begin{tabular}{cccc}
\hline \hline $\begin{array}{c}\text { Nomor } \\
\text { Klaster }\end{array}$ & Jumlah Tweet & Total Retweet & Rata-Rata Retweet \\
\hline 1 & 15 & 11 & 0,733 \\
2 & 7 & 45 & 6,249 \\
3 & 8 & 13 & 1,625 \\
$\vdots$ & $\vdots$ & $\vdots$ & $\vdots$ \\
26 & 9 & 1 & 0,111 \\
27 & 18 & 32 & 1,778 \\
28 & 9 & 139 & 15,444 \\
\hline \hline
\end{tabular}

Berikut adalah grafik rata-rata jumlah retweet tiap klaster:

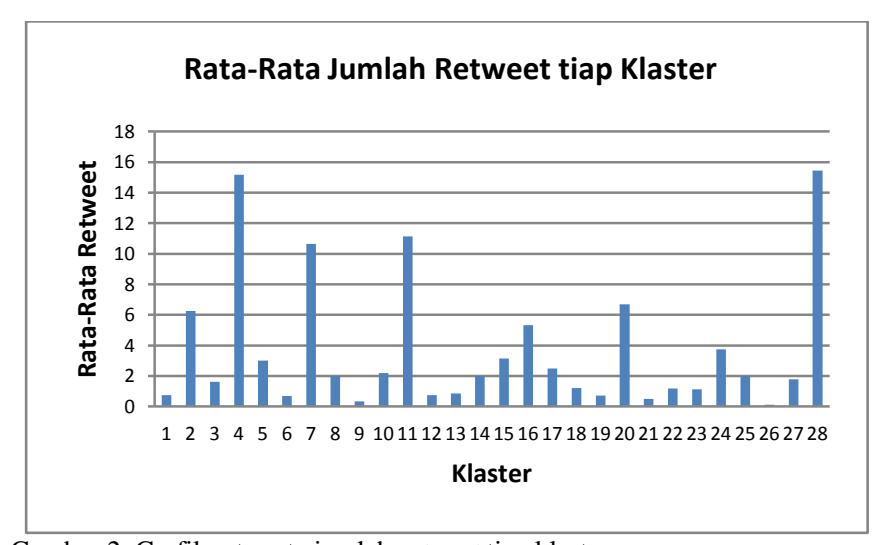

Gambar 2. Grafik rata-rata jumlah retweet tiap klaster.

Berdasarkan hasil di atas didapatkan bahwa klaster yang memiliki jumlah rata-rata retweet tinggi diantaranya klaster 28, klaster 4, klaster 11, klaster 7, dan klaster 20, sedangkan klaster yang memiliki jumlah rata-rata retweet rendah diantaranya klaster 26, klaster 9, klaster 21, klaster 1, dan klaster 6. Jenis konten pada klaster yang memiliki jumlah retweet yang tinggi diantaranya tentang kuis berhadiah (klaster 4, klaster 20, dan klaster 28), ulang tahun Shopee Indonesia (klaster 11), dan hobi, kuis, dan lifestyle (klaster 7), sedangkan jenis konten pada klaster yang memiliki jumlah retweet yang rendah diantaranya tentang kode voucher untuk potongan harga (klaster 1), pengumuman kuis pemenang (klaster 6), Mobile Shopping Day (klaster 9), kontes foto Valentine (klaster 21), dan pengumuman pemenang Seller of The Month (klaster 26).

\section{ANALISIS}

\section{A. Analisis Hasil Clustering dengan Metode K-means}

Salah satu metode yang digunakan untuk menguji kualitas klaster yang dihasilkan dari proses clustering adalah Silhouette Coefficient.

Tabel 10.

Perhitungan silhouette coefficient pada tiap klaster tweet

\begin{tabular}{ccc}
\hline \hline $\begin{array}{c}\text { Nomor } \\
\text { Klaster }\end{array}$ & Jumlah Tweet & Nilai Silhouette Coefficient \\
\hline 1 & 15 & 0,22 \\
2 & 7 & 0,35 \\
3 & 8 & 0,1 \\
$\vdots$ & $\vdots$ & $\vdots$ \\
26 & 9 & 0,13 \\
27 & 18 & $-0,01$ \\
28 & 9 & 0,15 \\
\hline \hline
\end{tabular}

Berikut adalah grafik nilai Silhouette Coefficient pada tiap klaster tweet:

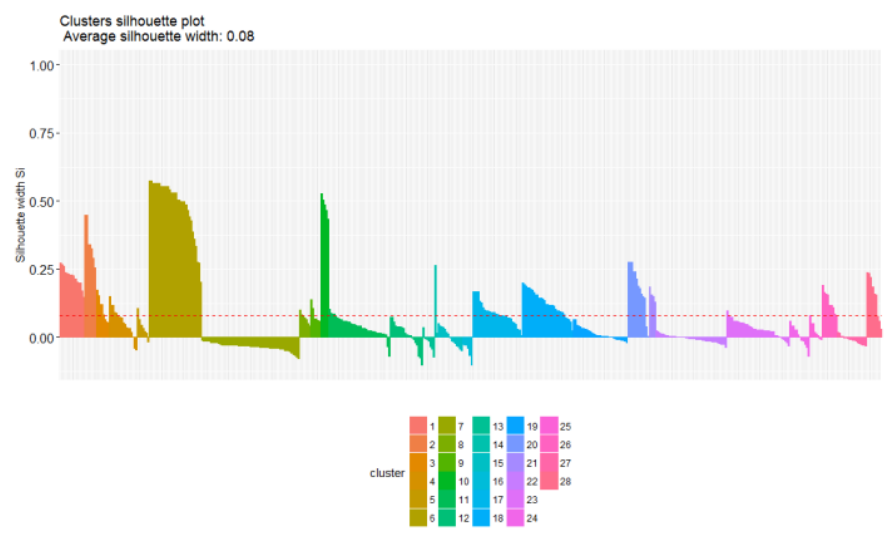

Gambar 3. Grafik nilai silhouette coefficient pada tiap klaster tweet.

Berdasarkan hasil perhitungan nilai Silhouette Coefficient di atas, diketahui sebanyak 21 klaster memiliki nilai positif, 3 klaster memiliki nilai 0 , dan 4 klaster memiliki nilai negatif. Nilai positif menunjukkan bahwa sebagian besar anggota pada klaster berada pada klaster yang tepat, nilai 0 menunjukkan bahwa sebagian besar anggota pada klaster berada di antara 2 klaster, dan nilai negatif menunjukkan bahwa sebagian besar anggota pada klaster berada pada klaster yang tidak tepat. Adanya nilai 0 dan nilai negatif menunjukkan bahwa hasil clustering dengan metode $k$-means pada data tweet masih belum optimal.

Terdapat beberapa faktor yang membuat hasil clustering dengan metode $k$-means pada data tweet masih belum optimal, diantaranya adalah sebagai berikut:

1. Batas maksimal karakter yang ada pada sebuah tweet adalah 140 karakter, sehingga sebagian besar tweet 
mengandung kata-kata yang berupa singkatan. Contoh: kata "untuk" menjadi "utk", kata "yang" menjadi "yg", kata "dengan" menjadi "dgn" dan lain sebagainya. Penggunaan kata singkatan berpengaruh terhadap proses stopword removal, dimana kata yang seharusnya dihilangkan menjadi tidak terdeteksi sehingga akan tetap ada pada kalimat tweet.

2. Tidak dilakukannya proses stemming dan tagging berakibat pada tweet yang sebenarnya memiliki maksud yang sama akan dianggap memiliki perbedaan karena penggunaan kalimat aktif dan pasif. Contoh: kalimat "kamu bisa mendapatkan hadiah ini" dan "hadiah ini bisa kamu dapatkan" akan memiliki perbedaan jarak dikarenakan terdapat kata yang berbeda yaitu "mendapatkan" dan "dapatkan".

Kedua faktor di atas sangat berpengaruh terhadap hasil dari proses clustering, dikarenakan setiap kata penyusun dari sebuah tweet akan menjadi variable-variable yang digunakan pada proses perhitungan jarak antar tiap tweet, sehingga hasil clustering dapat menempatkan tweet pada klaster yang tidak tepat.

\section{B. Analisis Hasil Penentuan Jenis Konten Tweet tiap Klaster}

Didapatkan hasil sejumlah 7 klaster memiliki jenis konten tweet yang sama yaitu tentang kuis berhadiah. Terdapat beberapa hal yang membuat tweet dengan jenis konten yang sama dapat berada pada klaster yang berbeda diantaranya:

1. Perbedaan penggunaan bentuk kalimat aktif dan pasif didalam menyampaikan isi dari tweet tersebut.

2. Adanya kata-kata penting yang menjadi pembeda antar tiap klaster seperti nama kuis dan hadiah yang didapatkan.

Meskipun terdapat beberapa klaster dengan jenis konten tweet tentang kuis berhadiah, tetapi masing-masing klaster memiliki jumlah retweet yang tinggi, sehingga tidak diperlukan analisis lebih lanjut mengenai kuis berhadiah seperti apa yang memiliki jumlah retweet tinggi.

\section{Analisis Pemilihan Jenis Konten Tweet untuk Sarana Advertising}

Berdasarkan hasil perhitungan rata-rata jumlah retweet pada tiap klaster, didapatkan bahwa jenis konten pada klaster yang memiliki jumlah retweet yang tinggi diantaranya tentang kuis berhadiah, ulang tahun Shopee Indonesia, dan hobi, kuis, dan lifestyle, sedangkan jenis konten pada klaster yang memiliki jumlah retweet yang rendah diantaranya tentang kode voucher untuk potongan harga, pengumuman kuis pemenang, Mobile Shopping Day, kontes foto Valentine, dan pengumuman pemenang Seller of The Month.

Hasil yang didapatkan menunjukkan bahwa konsumen dari pelaku bisnis Shopee Indonesia lebih tertarik terhadap program kuis berhadiah dibandingkan dengan promo atau acara yang memberikan potongan harga. Sehingga pelaku bisnis Shopee Indonesia diharapkan untuk memanfaatkan jenis konten tweet berupa kuis berhadiah sebagai sarana untuk melakukan advertising dibandingkan promo atau acara yang memberikan potongan harga. Selain itu, undian atau kuis berhadiah dapat memberikan dorongan kepada konsumen untuk melakukan pembelian dalam jumlah yang lebih banyak dan meminimumkan perilaku ganti-ganti merek [11]. Sedangkan potongan harga dapat mempengaruhi jumlah penjualan dengan adanya percepatan pembelian, tetapi memiliki dampak negatif terhadap ekuitas merek [12].

\section{KESIMPULAN}

Kesimpulan yang dapat ditarik pada penelitian ini adalah sebagai berikut:

1. Penerapan algoritma proses Text Mining untuk melakukan clustering dengan metode $K$-means pada data tweet Shopee Indonesia menghasilkan sejumlah 28 klaster tweet.

2. Berdasarkan hasil proses penentuan jenis konten dan perhitungan rata-rata jumlah retweet pada tiap klaster, didapatkan bahwa jenis konten pada klaster yang memiliki jumlah retweet yang tinggi diantaranya tentang kuis berhadiah (klaster 4, klaster 20, dan klaster 28), ulang tahun Shopee Indonesia (klaster 11), dan hobi, kuis, dan lifestyle (klaster 7).

3. Pelaku bisnis Shopee Indonesia dapat mengetahui jenis konten tweet yang banyak dilakukan retweet oleh followers-nya sehingga dapat menggunakan jenis konten tweet tersebut sebagai sarana untuk melakukan advertising kepada pengguna Twitter.

\section{LAMPIRAN}

Berikut adalah jenis konten tweet pada tiap klaster:

Tabel 11.

Kata paling sering muncul dan jenis konten tweet pada tiap klaster

\begin{tabular}{|c|c|c|}
\hline $\begin{array}{l}\text { Nomor } \\
\text { Klaster }\end{array}$ & Kata Paling Sering Muncul & Jenis Konten Tweet \\
\hline 1 & $\begin{array}{l}\text { gunakan, kode, voucher, } \\
\text { dapatkan, potongan, untuk, } \\
\text { kategori, berlaku, hari, ini }\end{array}$ & $\begin{array}{l}\text { Kode voucher untuk } \\
\text { potongan harga }\end{array}$ \\
\hline 2 & $\begin{array}{l}\text { ayo, ikutan, kuis, di, fbig, } \\
\text { shopee, ya, orang, yang, } \\
\text { beruntung }\end{array}$ & Kuis berhadiah \\
\hline 3 & $\begin{array}{l}\text { tunjukin, foto, kamu, gaya, } \\
\text { belanja, terbaik, hari, ini, } \\
\text { dapatkan, iphone }\end{array}$ & $\begin{array}{l}\text { Kontes foto saat } \\
\text { berbelanja }\end{array}$ \\
\hline 4 & $\begin{array}{l}\text { mau, yuk, ikutan, kuisnyashebi, } \\
\text { shopee, keren, kamu, klik, } \\
\text { acara, beli }\end{array}$ & Kuis berhadiah \\
\hline 5 & $\begin{array}{l}\text { terima, kasih, media, acara, } \\
\text { hari, ceo, shopee, indonesia, } \\
\text { chris, feng }\end{array}$ & $\begin{array}{l}\text { Press conference CEO } \\
\text { Shopee Indonesia }\end{array}$ \\
\hline 6 & $\begin{array}{l}\text { selamat, kepada, pemenang, } \\
\text { kuis, kali, ini, untuk, } \\
\text { konfirmasi, silahkan, kirim }\end{array}$ & $\begin{array}{l}\text { Pengumuman pemenang } \\
\text { kuis }\end{array}$ \\
\hline 7 & $\begin{array}{l}\text { shebi, kamu, nonton, film, } \\
\text { shopeeid, ayo, satu, bikin, cari, } \\
\text { hobby }\end{array}$ & Hobi, kuis, dan lifestyle \\
\hline 8 & $\begin{array}{l}\text { shopeeholics, seller, yang, kota, } \\
\text { ayo, ikutan, kampus, shopee, } \\
\text { roadshow }\end{array}$ & $\begin{array}{l}\text { Kampus Shopee } \\
\text { Roadshow }\end{array}$ \\
\hline 9 & $\begin{array}{l}\text { di, shopee, mobile, shopping, } \\
\text { day, prep, yuk, tips, contest, } \\
\text { lihat }\end{array}$ & Mobile Shopping Day \\
\hline 10 & $\begin{array}{l}\text { yakin, udah, tahu, shopee, } \\
\text { jawab, pertanyaan, ini, di, igfb, } \\
\text { dapatkan }\end{array}$ & Kuis berhadiah \\
\hline
\end{tabular}


conference, shopee, birthday, shopeebirthday, cek, live, facebook, yuk, beli, fbig gunakan, kode, voucher, dptkn, diskon, utk, belanja, untuk, kategori, pria

hari, utk, bulan, cinta, diskon,

13 shopee, voucher, grosir, mulai, februari

14 crazy, gadget, flash, sale, cuma, jam , aja, besok, bakal, acc hari, ada, samsung, galaxy,

15 diskon, harga, pukul, wib, stock, terbatas

ayo, ikutan, kuis, di, fbig, shopee, ya, orang, yang, beruntung

happy, weekend, shopeeholics, selamat, hari, untuk, merayakan, quoteoftheday, have, day

mobile, accessories, flash, sale hari, ini, dimulai, jam, cek, koleksinya dapatkan, berbagai, shopee,

19 klik, beli, untuk, hari, ini, aja, loh

Ulang tahun Shopee Indonesia

Kode voucher untuk dapatkan diskon

Bulan Cinta Diskon

Crazy Gadget Flash Sale

Diskon produk dengan stock terbatas

Kuis berhadiah

Ucapan selamat happy weekend dan hari spesial

Mobile Accessories

Flash Sale

Promosi beberapa produk

Kuis berhadiah shopee, ya, orang, yang, beruntung

valentine, sang, buah, hati, ayo,

21 upload, foto, caption, paling, kreatif ayo, cobain, bikin, nih, shebi, kasih, lihat, resepnya, untuk, kamu ayo, belanja, koleksi, termurah, shopee, diskon, loh, yuk, cek, koleksinya mau, merchandise, film, yuk, cek, fbig, shopee, untuk, info,

Kontes foto Valentine

Resep masakan dari

Shebi

Promo diskon beberapa produk

Kuis berhadiah lengkapnya ada, unboxing, google, pixel,

25 di, facebook, shopee, live, jam, wib

ini, dia, pemenang, seller, of,

26 the, month, bulan, vote, terbanyak
Pengumuman pemenang Seller of The Month

\section{DAFTAR PUSTAKA}

[1] E. B. George and A. B. Michael, Advertising and Promotion: An Marketing Communications Perpective. New York: The McGraw-Hill Companies, 2003.

[2] S. Neti, "Social Media and its Role in Marketing," J. Enterp. Comput. Bus. Syst., vol. 4, 2011.

[3] Kementrian Perdagangan, "Panduan Optimalisasi Media Sosial Untuk Kementrian Perdagangan RI," Jakarta, 2014.

[4] M. Rani and J. Arora, "Twitter Data Predicting Geolocation Using Data Mining Techniques," Int. J. Innov. Res. Comput. Commun. Eng., 2016.

[5] Twitter, "Analitika Twitter," 2016. [Online]. Available: https://business.twitter.com/id/analytics.html.

[6] Twitter, "Company," $2016 . \quad$ [Online]. Available: https://about.twitter.com/id/company.

[7] Twitter, "Getting Started With Twitter," 2016. [Online]. Available: https://help.twitter.com/forms.

[8] Y. Zhao, $R$ and Data Mining: Examples and Case Studies. Amsterdam: Elsevier, 2013.

[9] R. Feldman and J. Sanger, The Text Mining Handbook: Advance Approaches in Analyzing Unstructured Data. New York: Cambridge University Press, 2007.

[10]C. C. Aggarwal and C. Zhai, Mining Text Data. New York: Springer US, 2012.

[11]F. Tjiptono, Brand Management \& Strategy. Yogyakarta: Andi Offset, 2005

[12] J. Manel, J., M.C. and S. Zacharias, "Sales Promotion Good or Bad?," in International Marketing Conference on Marketing \& Society, 2007. 